\title{
AN EVALUATION OF THE EUGLOBULIN METHOD FOR THE DETERMINATION OF FIBRINOLYSIS
}

\author{
BY \\ E. KOWALSKI, M. KOPEC, AND S. NIEWIAROWSKI \\ From the Laboratory for Clinical Biochemistry, Institute of Haematology, Warsaw, Poland
}

(RECEIVED FOR PUBLICATION NOVEMBER 11, 1958)

Methods for determining fibrinolysis are not satisfactory. The reproducibility and accuracy of many known methods are doubtful, and it is difficult to say how far they reflect the processes and the fibrinolytic potential in the living organism, so in this paper will be presented the results of many years' experience with the euglobulin method.

\section{Methods and Materials}

Reagents.-The reagents are $0.1 \mathrm{M}$ ammonium oxalate in distilled water, and a borate solution made up of $9 \mathrm{~g}$. sodium chloride and $1 \mathrm{~g}$. sodium borate in $1,000 \mathrm{ml}$. distilled water.

Streptokinase was purchased from Warszawska Wytwórnia Surowic i Szczepionek.

Fibrinogen was prepared by the method of Kekwick, Mackay, Nance, and Record (1955).

Thrombin was prepared after separating prothrombin by the method of Lewis and Ferguson (1953) slightly modified. Prothrombin was converted to thrombin using the calcium-thromboplastin mixture, and thrombin was precipitated by acetone and extracted from the acetone-dried powder with distilled water.

The euglobulin precipitation is based on an early observation of Milstone (1941) and Macfarlane and Biggs (1948) that plasminogen is a chief component of the euglobulin fraction. The method, as used here, has been worked out by Kowarzyk and Buluk (1950).

Method.-Blood was collected into $0.1 \mathrm{M}$ ammonium oxalate in the proportion of 1 part of anticoagulant to 9 parts of blood, and plasma was obtained by centrifuging for 10 minutes at 1,500 r.p.m. To $0.5 \mathrm{ml}$. of plasma $8 \mathrm{ml}$. distilled water and $0.15 \mathrm{ml} .1 \%$ acetic acid were added. The $\mathrm{pH}$ should be approximately 5.2. After 30 minutes' incubation in a refrigerator at $+4^{\circ} \mathrm{C}$. the tubes were centrifuged for five minutes at 1,500 r.p.m. The supernatant was poured off and the tubes were drained by inverting on filter paper for about one minute. The precipitate was dissolved with the aid of a fine glass rod in $5 \mathrm{ml}$. borate solution, and the tubes were placed in a waterbath at $37^{\circ} \mathrm{C}$. After a few minutes $0.5 \mathrm{ml} .0 .025 \mathrm{M}$ calcium chloride was added. The clot which formed within a few minutes was observed every 10 minutes and the lysis time recorded.
As shown by Copley, Niewiarowski, and Marechal, in co-operation with this laboratory, it is possible to utilize this method for volumes of plasma as small as $50 \mu 1$.

Other Determinations.-Fibrinolysis in whole plasma and recalcification time were determined by the method of Biggs and Macfarlane (1957); total protein in plasma and in euglobulin fractions was determined by the method of Weichselbaum (1946); trichloracetic acid-soluble tyrosine was determined by the method of Folin and Ciocalteu (1927), fibrinogen and the prothrombin index were determined by the methods of Quick $(1935,1957)$; plasminogen was determined by the method of Kowalski, Latallo, and Niewiarowski (1956); antiplasmin by the method of Niewiarowska (1957); two-stage prothrombin by the method of Leonow (1950) ; Factor V by the method of Wolf (1953) ; and Factor VII by the method of Koller, Loeliger, and Duckert (1951); antihaemophilic globulin and Christmas factor were determined by the method of Pitney (1956).

\section{Results}

To evaluate the usefulness of the euglobulin method for the clinician, results obtained by examining 292 normal subjects were submitted to a statistical analysis carried out in the course of seven years by different workers. It can be seen from Table $I$ that the mean lysis time for several sets of results showed only negligible variations from 210 to 221 minutes. The frequency shows a Gaussian distribution (Fig. 1).

TABLE I

FIBRINOLYSIS IN EUGLOBULIN OF NORMAL SUBJECTS

\begin{tabular}{|c|c|c|c|c|c|c|}
\hline Authors & $\begin{array}{c}\text { No. } \\
\text { of } \\
\text { Cases }\end{array}$ & $\begin{array}{l}\text { Mean } \\
\text { (min.) }\end{array}$ & $\begin{array}{c}\text { Stan- } \\
\text { dard } \\
\text { Devia- } \\
\text { tion }\end{array}$ & $\begin{array}{l}\text { Stan- } \\
\text { dard } \\
\text { Error }\end{array}$ & $\begin{array}{c}\text { Maxi- } \\
\text { mal } \\
\text { Value }\end{array}$ & $\underset{\text { Mini- }}{\text { Malue }}$ \\
\hline $\begin{array}{l}\text { Kowarzyk and } \\
\text { Buluk (1950) } \\
\text { Kopeć et al. (1952) } \\
\text { Kopeć and Niewia- } \\
\text { rowski (1956) } \because \\
\text { Kowalski, Kopeć, } \\
\text { and Niewiarowski } \\
\text { (Present series). }\end{array}$ & $\begin{array}{r}90 \\
156 \\
46\end{array}$ & $\begin{array}{l}210 \\
216 \\
219 \\
\\
221\end{array}$ & $\begin{array}{l} \pm 67 \\
\pm 61 \\
\pm 54\end{array}$ & $\begin{array}{l} \pm 7 \\
\pm 5 \\
\pm 7.97\end{array}$ & $\begin{array}{l}340 \\
365 \\
340\end{array}$ & $\begin{array}{l}20 \\
45 \\
46\end{array}$ \\
\hline
\end{tabular}






FIG. 1.-Fibrinolysis in euglobulins of normal subjects.

To determine the usefulness of this method in demonstrating disturbances of fibrinolysis in various conditions, results obtained in the investigation of selected groups of subjects were analysed. It can be seen from Fig. 2 that in normal subjects after adrenaline injection the euglobulin fibrinolysis time is shortened. In rheumatoid arthritis and in chronic lung disease (Kopeć, Niewiarowski, and Kowalski, 1952), fibrinolysis time is lengthened. In patients on dicoumarol therapy fibrinolysis time is lengthened; this has been shown in a separate paper by Niewiarowska and Wegrzynowicz (1958). Patients with cirrhosis of the liver show only insignificant shortening of euglobulin fibrinolysis time.

To obtain more information about the theoretical basis of the euglobulin method certain

TABLE II

SOME FEATURES OF COAGULATION AND FIBRINOLYTIC SYSTEM OF EUGLOBULINS COMPARED WITH PLASMA

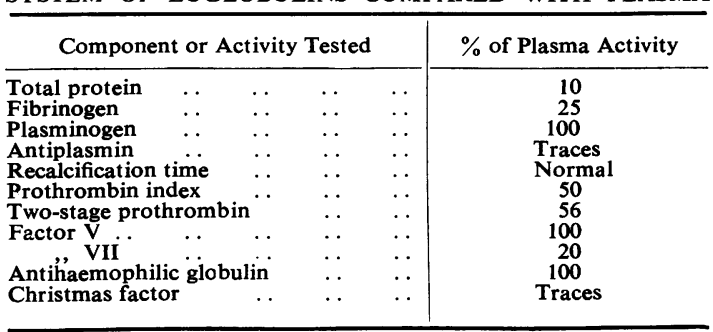

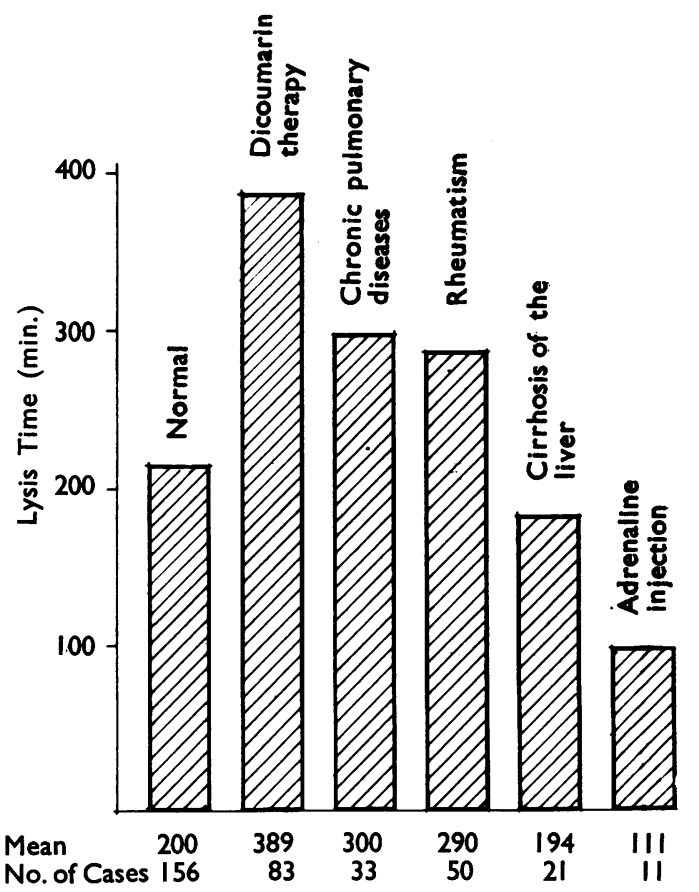

FIG. 2.-Euglobulin lysis time in various conditions.

biochemical studies were performed. Table II shows the most important components and activities of the coagulation and fibrinolysis system in euglobulin solution compared with plasma.

It can be seen that the euglobulins, which amount to $10 \%$ of the total plasma proteins, contain all the plasminogen, factor $\mathrm{V}$, and antihaemophilic activity, but that the amounts of

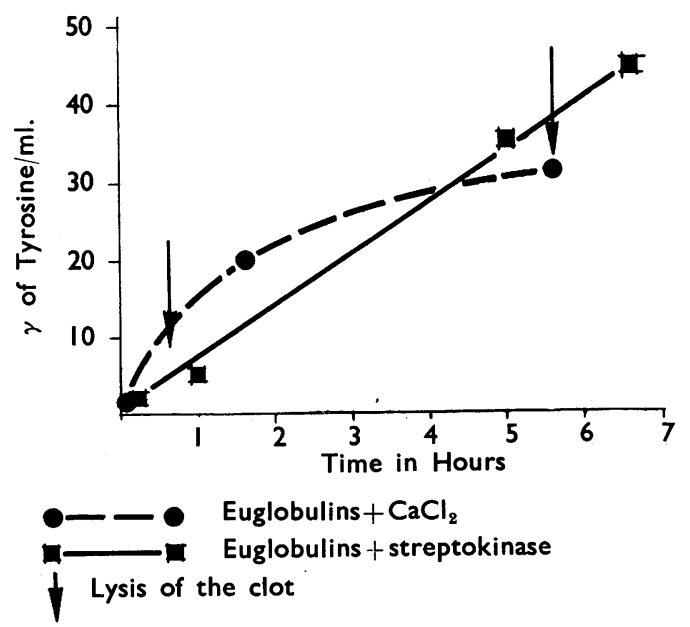

FIG. 3.-Proteolysis and fibrinolysis in euglobulins after the addition of $\mathrm{CaCl}_{2}$ or streptokinase. 


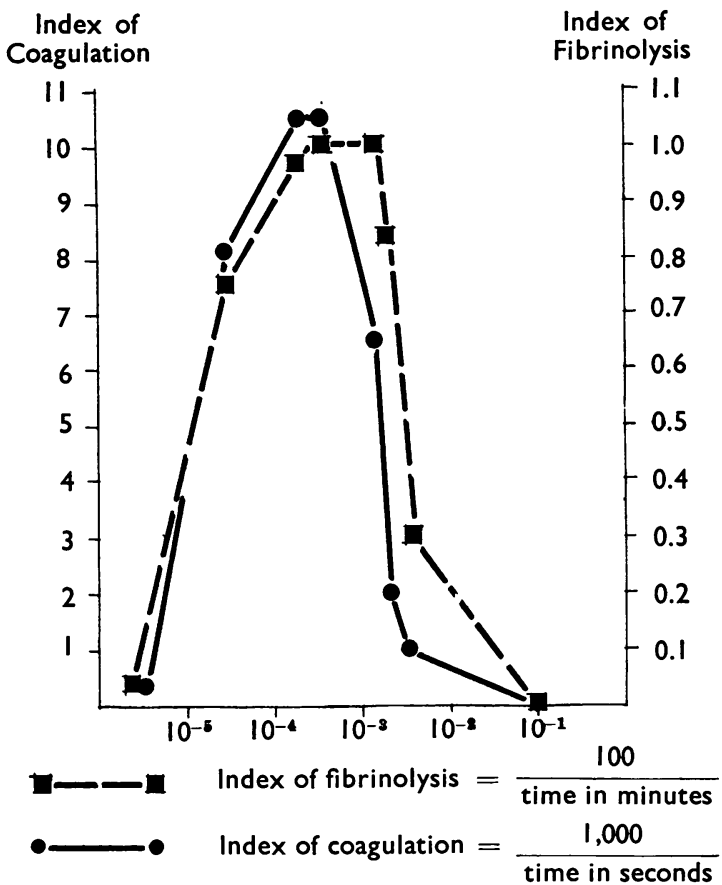

FIG. 4.-The influence of calcium concentration on the coagulation time and on the time of fibrinolysis in euglobulins.

fibrinogen, factor VII, and Christmas factor are considerably reduced. Euglobulins contain only traces of antiplasmin.

Figs. 3 and 4 show some essential features of euglobulin activation. Fig. 3 shows that $\mathrm{Ca}^{++}$ activation differs from streptokinase activation in that the $\mathrm{Ca}^{++}$activation has released more trichloracetic acid-soluble tyrosine compounds at the time of clot lysis. Streptokinase-induced fibrinolysis occurs earlier and is associated with the release of less tyrosine.

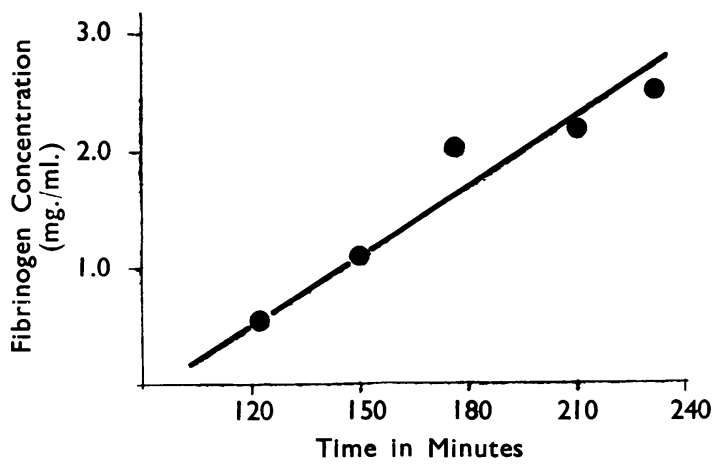

Fig. 5.-The influence of fibrinogen concentration on the euglobulin fibrinolysis time.
TABLE III

RELATION BETWEEN PLASMA FIBRINOGEN LEVEL AND EUGLOBULIN LYSIS TIME

\begin{tabular}{|c|c|c|c|c|c|c|c|c|c|c|c|c|c|c|}
\hline \multirow[b]{2}{*}{$\begin{array}{l}\text { Fibrinogen } \\
\text { (mg. ml.) }\end{array}$} & \multicolumn{14}{|c|}{ Lysis Time in Minutes } \\
\hline & ర్లి & $\begin{array}{l}\stackrel{8}{0} \\
\frac{1}{m}\end{array}$ & $\frac{8}{1}$ & $\frac{8}{\frac{1}{a}}$ & $\frac{n}{\frac{1}{1}}$ & $\frac{\infty}{\frac{1}{n}}$ & $\frac{\stackrel{0}{\tau}}{\frac{1}{\infty}}$ & $\begin{array}{c}\stackrel{q}{N} \\
\frac{1}{\bar{N}} \\
\end{array}$ &  & $\frac{8}{1}$ & 유 & $\underset{\substack{0 \\
\frac{1}{m}}}{2}$ & $\begin{array}{l}\stackrel{8}{7} \\
\frac{1}{6} \\
\end{array}$ & 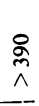 \\
\hline $\begin{array}{r}0-1 \\
1 \cdot 1-2 \\
2 \cdot 1-3 \\
3 \cdot 1-4 \\
4 \cdot 1-5 \\
5 \cdot 1-6 \\
6 \cdot 1-7\end{array}$ & & 1 & $\begin{array}{l}3 \\
2 \\
2\end{array}$ & $\begin{array}{l}5 \\
8 \\
1\end{array}$ & $\begin{array}{r}1 \\
10 \\
1 \\
5 \\
2 \\
2\end{array}$ & $\begin{array}{l}2 \\
4 \\
5 \\
1 \\
1\end{array}$ & \begin{tabular}{|l|}
3 \\
4 \\
2 \\
4
\end{tabular} & $\begin{array}{l}1 \\
3 \\
5 \\
6 \\
4\end{array}$ & $\begin{array}{l}1 \\
2 \\
2 \\
3 \\
4 \\
2\end{array}$ & $\begin{array}{l}2 \\
2 \\
2 \\
1\end{array}$ & $\begin{array}{l}1 \\
1 \\
1\end{array}$ & $\begin{array}{l}1 \\
2\end{array}$ & 1 & \\
\hline
\end{tabular}

Fig. 4 presents the interrelationship between clotting and fibrinolysis in euglobulins. It can be seen that optimum clotting ability and maximum fibrinolysis occur at approximately the same calcium concentrations.

To investigate the effect of the fibrinogen concentration in the euglobulin fraction on the lysis time, increasing amounts of fibrinogen were added to the euglobulin fraction, but there is no correlation between the fibrinogen concentration in plasma and the euglobulin fibrinolysis time; this is shown (Table III) in a group of normal subjects and in patients with various conditions.

There is also no correlation between the fibrinolytic activity of whole plasma and fibrinolysis time in the euglobulin fraction as shown in Fig. 6.

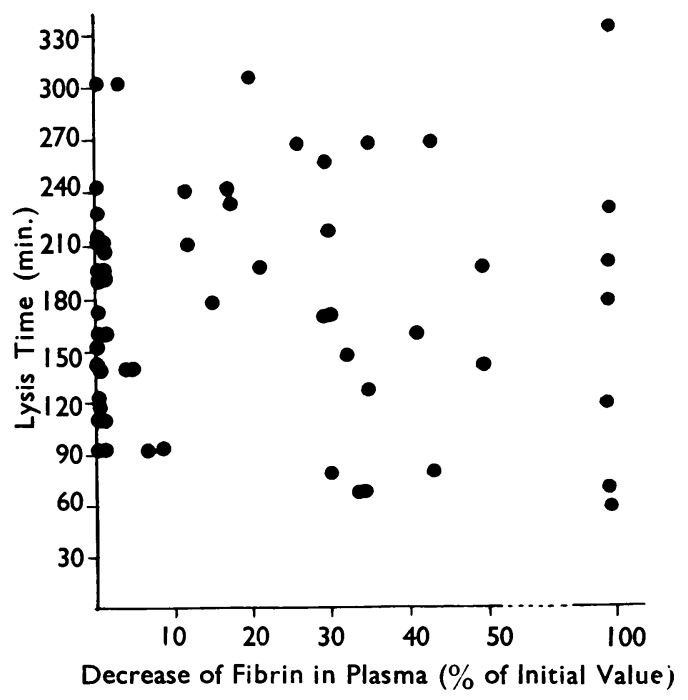

FIG. 6.-Relation between fibrinolysis in euglobulins and in whole plasma. 


\section{Discuscion}

The biochemical data presented show that there are essential differences between fibrinolysis in euglobulins and whole plasma. $\mathrm{Ca}^{++}$activation as done by the euglobulin method cannot be considered as physiological. Rechnic, Siwinska, and Czerwinska (1957) and Buluk and Januszko (1957) have shown that the mechanism of activation of fibrinolysis in euglobulins is connected with a decrease of antiplasmin during thrombinogenesis. For this and other reasons euglobulin lysis does not reflect the real fibrinolytic potential in the organism. It was shown in confirmation that lysis time in the euglobulin fraction differs from fibrinolysis in whole plasma.

In some diseases, e.g., in cirrhosis of the liver, it is possible to show enhancement of fibrinolysis by whole plasma and by Dausset's method (Dausset, Paraf, Bergerot-Blondel, and Caroli, 1956) while the euglobulin method shows only insignificant changes.

Nevertheless, as seen from the material presented, the euglobulin method can be helpful in discovering disturbances in the fibrinolytic system, e.g., after the injection of adrenaline the euglobulin lysis time is always shortened. It seems that the lengthening of fibrinolysis time in chronic lung diseases can also be demonstrated adequately by this method (Kopec et al., 1952).

To some extent the value of the euglobulin method lies in the possibility of comparing large groups of patients and of drawing some conclusions about the nature of the fibrinolytic system. Various workers have used this method to show the activation of fibrinolysis in patients with tumours (Taper, 1956) and in patients with insulin hypoglycaemias (Hintz, 1956) and also to show diurnal variations of fibrinolytic activity (Kaniak, Siwinska, Krakowska - Rechnicowa, Iwankiewicz, and Kornaszewski, 1957).

Niewiarowski and Panasewicz (1954) used this method to demonstrate activation of the fibrinolytic system in heterogenic post-transfusional shock in animals and Niewiarowska (1957) in a study of physiological hypothermia.

\section{Summary}

The authors present the results of several years' experience of the application of the euglobulin method to determine fibrinolysis in human plasma. The results suggest that this method is valuable for clinical purposes, especially for the comparative assay of fibrinolytic systems in large groups of patients. The recovery of several factors of the clotting and fibrinolytic system in the euglobulin fraction is presented. Different types of activation of fibrinolysis in euglobulins are described. The biochemical background of the method is briefly discussed.

\section{REFERENCES}

Biggs, R., and Macfarlane, R. G. (1957). Human Blood Coagulation and its Disorders, 2nd ed. Blackwell Scientific Publications, Oxford. Buluk, K., and Januszko, T. (1957). Arch. Immunol. Ter. dosw.,

Copley, A. L., Niewiarowski, S., and Marechal, J. J. Lab. clin. Med. In press.

Dausset, J., Paraf, A., Bergerot-Blondel, Y., and Caroli, J. (1956). Semaine des Hôpitaux; Pathologie et Biologie, No. XIII; Ann. Rech. méd., Nr. 6, 32, 473.

Folin, O., and Ciocalteu, V. (1927). J. biol. Chem., 73, 627

Hintz, R. (1956). Pol. Arch. Med. wewnet, 26, 177.

Kaniak, J., Siwinska, M., Krakowska-Rechnicowa, J., Iwankiewicz, S., and Kornaszewski, W. (1957). Postepy Hig. Med. dósw., 11,

Kekwick, R. A., Mackay, M. E., Nance, M. H., and Record, B. R. (1955). Biochem. J., 60, 67i.

Koller, F., Loeliger, A., and Duckert, F. (1951). Acta haemat. (Basel), 6, 1.

Kopeć, M., and Niewiarowski, S. (1956). Pol. Arch. Med. wewnet, 26, 1321 . 26, I321. Kowalski, E. (1952). Pamietnik, II Zjazdu Pol. Tow. Hematol., Gdansk, 229.

Kowalski, E., Latallo, Z., and Niewiarowski, S. (1956). Acta biochim. pol., 3, 87.

Kowarzyk, H., and Buluk, K. (1950). Postepy Hig. Med. dosw., 2, 1.

Leonow, A. (1950). Przegl. lek., 6, 765.

Lewis, J. H., and Ferguson, J. H. (1953). J. clin. Invest., 32, 915.

Macfarlane, R. G., and Biggs, R. (1948). Blood, 3, 1167.

Milstone, H. (1941). J. Immunol., 42, 109.

Niewiarowska, M. (1957). Rev. Hémat., 12, 650.

- and Wegrzynowicz, Z. (1958). IVth International Congress of Biochemistry, Vienna.

Niewiarowski, S., and Panasewicz, J. (1954). Bull. Acad. pol. Sci. Cl. $2,2,121$.

Pitney, W. R. (1956). Brit. J. Haemat., 2, 250.

Quick, A. J. (1935). J. biol. Chem., 109, Ixxiii.

- (1957). The Physiology and Pathology of Hemostasis. Lea and Febiger, Philadelphia.

Rechnic, M., Siwinska, M., and Czerwinska, B. (1957). Arch. Immunol. Ter. dosw., 5, 347.

Taper, H. (1956). Pol. Tyg. lek., 11, 107.

Weichselbaum, T. E. (1946). Amer. J. clin. Path., 16, Tech. Bull., $7,40$.

Wolf,'P. (1953). J. clin. Path., 6, 34. 